\title{
PERSEPSI MASYARAKAT DALAM MENANGGAPI IKLAN POLITIK DI TELEVISI
}

\author{
Fajar Yusuf Abadi, Agus Tinus, Rohmad Widodo, Rose Fitria Lutfiana \\ Universitas Muhammadiyah Malang Program Studi Pendidikan Pancasila dan Kewarganegaraan \\ Email: rose@umm.ac.id
}

\begin{abstract}
This study aims to describe (1) people's perceptions in responding to political advertising on television; (2) the impact of political advertising on people's suffrage. The descriptive qualitative research method was carried out in Setail Village. Data collection is done through observation, interviews, and documentation. Data analysis includes several steps accompanied by data validity using the Triangulation procedure. The results showed: (1) Public perception in responding to political advertising on television that it was fairly good and effective. Associated with public perception that political advertising is able to add insight, be able to identify and sort out prospective participants, know the vision and mission, know the programs offered, and television with audio visuals can form an image of its own attraction (2) The impact of political advertising on television on voting rights the public that political advertising has advantages and disadvantages. Its strengths include adding political insight, being able to sort and select potential participants, increase participation, and encourage opinion. The disadvantages include, the message content is sometimes unclear, interpretation constraints, the truth of the content, and can affect the conditions of belief. The conclusion is that political advertising activities on television are effective because one of them is able to cover a wide audience, related to the suffrage of the community said to increase participation, but political advertising accompanied by image and opinion coupling can influence and become a separate consideration for the community.
\end{abstract}

Keywords: Perception, Political Advertising, Television 


\begin{abstract}
Abstrak
Penelitian ini bertujuan untuk mendeskripsikan (1) persepsi masyarakat dalam menanggapi iklan politik di televisi; (2) dampak iklan politik terhadap hak pilih masyarakat. Metode penelitian menggunakan deskriptif kualitatif dilakukan di Desa Setail. Pengumpulan data dilakukan melalui observasi, wawancara, dan dokumentasi. Analisis data meliputi beberapa tahap disertai dengan keabsahan data menggunakan prosedur Triangulasi. Hasil penelitian menunjukkan: (1) Persepsi masyarakat dalam menanggapi iklan politik di televisi bahwasanya hal tersebut terbilang bagus dan efektif. Terkait dengan persepsi masyarakat bahwasanya iklan politik mampu menambah wawasan, bisa mengenal dan memilah memilih calon peserta, mengetahui visi misi, mengetahui progam yang ditawarkan, serta televisi dengan audio visualnya dapat membentuk citra daya tarik tersendiri (2) Dampak iklan politik di televisi terhadap hak pilih masyarakat bahwasanya iklan politik memiliki kelebihan dan kekurangan. Kelebihannya diantaranya menambah wawasan politik, dapat memilah dan memilih calon peserta, meningkatkan partisipasi, dan penggiringan opini. Kekurangannya diantaranya, isi pesan terkadang kurang jelas, kendala penafsiran, kebenaran isi, dan dapat mempengaruhi kondisi keyakinan. Kesimpulannya ialah bahwa kegiatan iklan politik di televisi efektif karena salah satunya mampu mencakup khalayak luas, terkait dengan hak pilih masyarakat dikatakan meningkatkan partisipasi, namun iklan politik disertai citra serta penggiringan opini dapat mempengaruhi dan menjadi pertimbangan tersendiri bagi masyarakat
\end{abstract}

Kata Kunci: Persepsi, Masyarakat, Televisi 


\section{Pendahuluan}

Media dan politik sangat erat hubungannya, karena salah satu fungsi dan tujuan media adalah untuk pembentukan karakter serta perilaku mengenai beberapa hal, baik itu dalam kehidupan sehari-hari seperti sosial, ekonomi, budaya, dan khususnya politik. Sekarang ini kita bukan lagi sedang menuju era kemajuan teknologi dan komunikasi, melainkan kita sekarang sudah berada dan melakukannya. Semakin maju dan canggih semua yang ada didalamnya khususnya teknologi didgital makin terintegrasnya masyarakat dan Negara. Instusi yang terkait didalamnya khususnya kegiatan politik dan pemerintah perlu membutuhkan suatu pendekatan alternatif untuk membangun suatu hubungan dengan masyarakat luas.

Berdasarkan fenomena ini maka kita tidak bisa terlepas dari konteks media dan marketing dengan segala disiplin ilmu didalamnya. Media massa menurut Cangara (2003) adalah alat yang digunakan dalam penyampaian pesan dari sumber kepada khalayak penerima dengan menggunakan alat komunikasi mekanis seperti surat kabar, film, radio, dan televisi. Media massa dan manusia sangat erat hubungannya, melalui media massa setiap manusia bisa mendapatkan informasi yang menyangkut dirinya, oranglain, maupun lingkungannya. Jadi, tanpa disadari dalam kehidupannya sehari-hari mereka berinteraksi dengan media.

Media massa secara umum dapat diartikan sebagai suatu wadah yang digunakan sebagai perantara ata pengirim pesan dengan maksud dan tujuan tertentu.Media massa menurut Tamburaka (2012) merupakan instusi yang menghubungkan seluruh unsur masyarakat satu dengan lainnya dengan melalui produk media massa yang dihasilkan. Kehidupan manusia pada saat ini bisa dikatakan tidak terlepas dari media massa baik itu cetak seperti koran, majalah maupun elektronik berupa radio, film, dan televisi.

Sejalan dengan kemajuan zaman, kehidupan masyarakat banyak mengalami perubahan, misalnya dalam hal berfikir kini menjadi modern. Menurut Setiadi \& Kolip (2013) masyarakat Indonesia dapat mengikat anggota sekitarnya melalui sistem yang biasa disebut kekerabatan. Pada umumnya sistem ini didasarkan pada prinsip demokrasi, baik itu dalam kehidupan sosial politik, ekonomi, budaya dan aspek hidup lainnya. Namun, ikatan yang paling kuat pada masyarakat adalah adanya pandangan hidup bangsa yaitu Pancasila serta dasar hukum nasional yaitu UUD 1945. Tentu meskipun adanya hal itu, perubahan masyarakat satu dengan lainnya akan memiliki perbedaan, kaitannya dalam hal ini adalah persepsi atau pemikiran.

Berbicara mengenai media dalam pembahasan ini adalah televisi, dimana dengan segala kelebihannya dan keterjangkauannya pada khalayak luas maka hal ini tidak terlepas dari suatu kepentingan tertentu khususnya politik. Menurut Cangara (2003) televisi memiliki kekuatan diantaranya memiliki kelebihan audio visual, kemampuan menampilkan gambar, penonton dimanjakan dengan progam acara, dapat menjangkau khalayak luas khususnya yang telah dialiri listrik dengan tidak terbatas jarak dan waktu. Televisi merupakan bagian dari media massa elektronik, televisi selain dijadikan media hiburan juga merupakan sarana wadah informasi dan komunikasi baik pendidikan maupun kepentingan tertentu.

Media dan politik bisa dikatakan telah menjadi bagian dari masyarakat dan tanpa disadari turut andil dalam kehidupannya. Politik itu adalah masyarakat itu sendiri, artinya bahwa kehidupan masyarakat tidak terlepas dari politik karena salah satu tujuannya ialah mempengaruhi, baik itu aturan, norma, dan kondisi keyakinan masyarakat. Peranan media memiliki pengaruh yang kuat dalam upaya pembentukan suatu kondisi dan keyakinan individu. Media dengan segala kehidupannya mampu memberikan berbagai informasi dan pengetahuan yang pada akhirnya akan membentuk persepsi dan keyakinan individu yang bisa mempengaruhi sikap dan perilakunya. 
Peranan media memiliki pengaruh yang kuat dalam upaya pembentukan suatu kondisi dan keyakinan individu. Media dengan segala kelebihannya mampu memberikan berbagai pesan informasi dan pengetahuan yang akhirnya akan mampu membentuk persepsi dan keyakinan individu yang bisa mempengaruhi sikap dan perilaku individu. Persepsi menurut Slameto (2010) merupakan proses yang berkaitan dengan masuknya pesan atau informasi ke dalam otak manusia, melalui persepsi mereka terus menerus mengadakan hubungan dengan lingkungannya. Kunci untuk memahami persepsi yaitu terletak pada bagaimana penafsiran akan sesuatu atau situasi dan bukannya suatu pencatatan yang benar terhadap situasi. Pada tahap ini mereka menggunakan indera mereka yaitu, penglihatan, pendengaran, penciuman, perabaan, dan perasa.

Periklanan politik melalui media televisi lebih efektif jika dibandingkan dengan poster, koran, spanduk dan lainnya, mengingat televisi dengan kemudahannya disertai kelebihannya yaitu audio visual dianggap menjadi citra daya tarik tersendiri bagi masyarakat yang menontonnya. Kekuatan yang dimiliki media televisi akan mampu membentuk sikap dan kepercayaan masyarakat, maka periklanan politik di televisi memang sudah seharusnya dilakukan dan khususnya menjadi sebuah kepentingan politik dan kampanye. Demikian pentingnya hal itu bagi keberhasilan pencapaian tujuan politik mereka, maka banyak partai politik dan calon pemimpin politik melakukan berbagai upaya untuk dapat menjadikan kondisi da keyakinan masyarakat dalam proses pengambilan keputusan.

Sebenarnya hal ini dimaksudkan agar semua kalangan khususnya dapat mudah mengenali dan menarik kesimpulan dari suatu partai politik dan aktifitas politik guna meningkatkan partisipasi dan wawasan politik masyarakat. Tetapi juga perlu dipertimbangkan karena semakin mudahnya kita menjangkaunya, kita untuk lebih meningkatkan filter dan waspada mengenai informasi yang disampaikan, mengingat politik dengan segala kepentingan didalamnya bisa jadi hal itu benar dan tidak menutup kemungkinan itu bisa juga berupa kebohongan.

Periklanan massa Secara umum merupakan komunikasi dari satu pihak kepada orang yang banyak, yang menjadi sasaran periklanan politik adalah individu tunggal bukan kelompok. Kaitannya dengan produk media massa Kuswandi (2008) mengatakan bahwasanya produk periklanan massa yang dihasilkan memberikan peranan besar dalam merubah gaya hidup dan perilaku seseorang berkenaan dengan pengambilan keputusan tindakan di lingkungannya. Hal inilah yang dirasa rentan terjadi dan patut diwaspadai oleh masyarakat khususnya agar terhindar dari terpecahnya kesatuan bernegara.

Periklanan politik juga dapat diartikan pembentukan suatu citra dan jati diri, dalam hal ini kaitannya adalah daya tarik untuk diarahkan membangun reputasi seseorang pejabat atau aktor politik, dan latar belakang yang bersangkutan. Berkenaan dengan iklan politik yang ditampilkan sejatinya telah termuat dalam PKPU (Peratutan Komisi Pemilihan Umum) Republik Indonesia Nomor 33 Tahun 2018, hal tersebut termuat pada pasal 37 yang berbunyi tentang kampanye disebutkan bahwa, paling sedikit iklan politik memuat tentang peserta pemilu, visi dan misi, serta mengenai program yang ditawarkan. Materi iklan tersebut dapat berupa tulisan, suara, gambar, dan gabungan antara tulisan, suara, gambar, yang bersifat naratif, berkarakter, serta dapat diterima melalui perangkat penerima pesan.

Penelitian mengenai iklan politik di televisi juga telah dilakukan oleh beberapa peneliti sebelumnya. Penelitian yang serupa dilakukan oleh Haryati (2007) dengan judul "Ketika Parpol Mengiklankan Kandidatnya di Televisi". Pada penelitian tersebut ditemukan bahwa politik tidak bisa terlepas dari media, kegiatan dan penggunaan iklan politik telah berlangsung sejak lama, dan lewat media cetak maupun elektronik dirasa 
lebih efektif serta dirasa mampu mencapai khalayak luas. Namun, efektifitas iklan politik di televisi dan pemenangan partai politik yang mengiklankan lewat media dirasa masih belum sepenuhnya bisa terwujud, jadi perlu adanya suatu kajian dan pertimbangan-pertimbangan tersendiri, khususnya bagi para calon yang ingin menggantungan pemenangan melalui media.

Penelitian lain yang serupa dilakukan oleh Priyanti (2013) dengan judul "Peranan Media Televisi dalam Pembentukan Perilaku Politik Berkenaan dengan Pilkada Jawa Tengah". Pada penelitian tersebut ditemukan bahwa iklan politik atau kegiatan politik di televisi bisa mempengaruhi perilaku politik masyarakat. Dengan semakin tertarik serta mengikuti aktifitas politik di televisi, masyarakat atau elemen lain bisa terpengaruh atau menjadi pertimbangan tersendiri dengan apa yang sedang berlangsung. Perilaku politik tersebut meliputi sikap, kondisi, keyakinan dan penentuan kedepan terhadap kegiatan politik. Jadi, melalui tayangan iklan politik yang telah masyarakat tonton sebelumnya, mereka menjadikan hal itu sebagai pertimbangan tersendiri dalam pengambilan keputusan kedepannya.

Selanjutnya penelitian oleh Boer (2014) dengan judul "Iklan Partai Politik dan Politik Media. Hasil temuan pada penelitian tersebut dikatakan bahwasanya iklan politik di media bagus dan efektif, namun dalam penyampaiannya harus dapat merangsang pemikiran positif. Namun juga dikatakan bahwasanya dalam penyampaian isi harus sesuai dengan visi misi kenyataan yang dijanjikan, karena banyak yang beranggapan bahwa iklan politik mampu membuat masyarakat dilemma dan terkadang juga malah tidak pecaya, khususnya dalam penyampaian progam-progam yang ditawarkan haruslah sewajarnya tidak usah melebih-lebihkan karena malah membuat masyarakat tidak percaya.

Penelitian lain yang serupa juga dilakukan oleh Shauma (2015) dengan judul "Efektifitas Iklan Politik di Televisi". Pada penelitian tersebut ditemukan bahwasanya periklanan politik di televisi dikategorikan bagus dan mampu menarik perhatian bagi penontonnya, khususnya dalam pengambilan suatu keputusan dikatakan iklan politik juga bisa mempengaruhi sikap dan pilihannya. Namun meskipun merupakan salah satu kegiatan yang bagus, periklanan politik di televisi belum bisa dikatakan efektif secara keseluruhan khususnya dalam mencakup anak atau remaja terkait dengan isi/kepentingan yang termuat didalamnya.

Selanjutnya penelitian oleh Mustofa (2013) dengan judul Peran Media Massa sebagai Sarana Iklan Politik Parpol. Pada penelitian tersebut ditemukan bahwasanya kegiatan kampanye salah satunya dengan iklan politik di media dikatakan bagus apalagi kita berada pada kebebasan pers dan kemajuan teknologi. Namun, kualitas yang ditayangkan dikatakan belum cukup kuat khususnya yang berkaitan dengan respon, akuntabilitas, dan keterbukaan. Hal tersebut juga dipengaruhi beberapa hal, khususnya money politik. Kegiatan tersebut juga dijadikan sebagai salah satu faktor pemicu cacat dalam persaingan pesta demokrasi yang notabennya guna kepentingan rakyat dan Negara. Namun meskipun banyak sekali bentuk-bentuk periklanan, masyarakat dari masa ke masa telah mengalami perubahan khususnya dalam hal pemikiran, kini masyarakat tidak sebodoh yang diperkirakan karena kini masyarakat telah pintar dalam hal pemaknaan tafsir, dan tidak mudah termakan oleh janji-janji dan terpengaruh khususnya elit politik.

Selanjutnya penelitian yang dilakukan oleh Yunus (2014) dengan judul "Konstruksi Pesan Politik di Televisi Komersial Menjelang Pemilu 2014). Pada penelitian tersebut ditemukan bahwasanya dalam penayangan iklan politik harus tersusun secara baik agar dapat tersampaikan kepada masyarakat serta tidak menghambat dalam penafsirannya. Kriteria dalam penyampaiannya diantaranya yaitu, appeals; attitudes and oppinions; likability; arguments; emotions; convictions. Untuk dapat menarik perhatian dikalangan 
masyarakat, disarankan memuat keberpihakan kepada rakyat kecil dan solusi-solusi yang nyata guna mensejahterakan rakyat.

Penelitian relevan selanjutnya oleh Magdalena (2010) dengan judul "Tanggapan Masyarakat Terhadap Iklan Politik di Televisi". Pada penelitian tersebut dikatakan bahwasanya masyarakat memahami bahwasanya iklan politik merupakan cara untuk meningkatkan popularitas dan diharapkan mampu menggerakkan elektabilitas yang bersangkutan. Iklan politik berisikan visi misi dan progam yang pro rakyat, dengan alasan itu merupakan senjata ampuh untuk membujuk dan mendukung tiap gagasan kepentingan politik.

Maka dapat diasumsikan bahwasanya setiap komunikasi dan indormasi yang dilakukan melalui media massa memiliki keunggulan dan kelemahan tersendiri. Maka berdasarkan uraian di atas, pendidikan dan sosialisasi politik dapat dilakukan oleh berbagai pihak dan lembaga, diantaranya oleh partai politik, pemerintah, dan media massa. Berdasarkan observasi yang telah dilakukan di Desa Setail Kecamatan Genteng Kabupaten Banyuwangi, bisa dikatakan masyarakat telah modern dan mengenal media serta terbiasa dapat mengikuti perkembangan zaman. Selanjutnya media massa elektronik televisi yang hampir dimiliki oleh tiap masyarakatnya dipilih karena ingin mengetahui keefektifannya, juga media televisi sangat besar pengaruhnya dalam penyebaran informasi dari tayangannya terhadap khalayak luas, dan bisa dikatakan akan mempengaruhi kondisi dan keyakinan tiap-tiap individu.

Namun, entah bagaimana mereka menangkap atau menafsirkan suatu pesan informasi kebanyakan masih belum mengerti dan kurangnya wawasan serta keberanian dalam menyimpulkan sesuatu keputusan. Masih perlu ditanamkannya suatu pendidikan politik yang nyata, khususnya oleh pmerintah guna terintegrasnya suatu masyarakat dan Negara yang baik. Untuk itu penelitian ini ditujukan untuk mengidentifikasi lebih lanjut mengenai sejauh mana persepsi masyarakat dalam menanggapi iklan politik di televisi, dan mengkaji dampak iklan politik terhadap hak pilih masyarakat.

Berdasarkan uraian di atas, peneliti tertarik untuk melakukan penelitian mengenai "Persepsi Masyarakat dalam Menanggapi Iklan Politik di Televisi di Dusun Curah Ketangi Desa Setail Kecamatan Genteng Kabupateng Banyuwangi”, sebagai upaya untuk mengidentifikasi bagaimana persepsi masyarakat dalam menanggapi iklan politik di televisi serta mengkaji dampak iklan politik terhadap hak pilih masyarakat.

\section{Metode}

Penelitian ini menggunakan jenis penelitian kualitatif dengan pendekatan deskriptif, dan instrumen penelitian adalah peneliti sendiri.

Penelitian ini bertempat di Desa Setail. Proses penyelesaian pada penelitian ini memerlukan waktu 1-6 bulan, dimulai pada bulan Desember 2018 sampai Mei 2019. Informan pada penelitian antara lain: (1) Perangkat Desa; (2) Panitia Pemilu 2019; (3) Kepala Dusun; (4) Tokoh Masyarakat dan Masyarakat.

Teknik pengumpulan data pada penelitian ini menggunakan: (1) Observasi, dilakukan pada tahap awal penelitian dengan terjun langsung ke lapangan, mengamati kegiatan beberapa masyarakat yang menonton televisi, kemudian observasi dilakukan mengenai peristiwa dengan mendengar dan melihat.

Wawancara, Pada tahap ini peneliti melakukan wawancara secara langsung dengan informan. (3) Dokumentasi.

Teknik analisis data terdiri dari tahapan diantaranya pengumpulan data, reduksi data, penyajian data, dan penarikan kesimpulan.

Tahap terakhir adalah upaya pengujian keabsahan data, dalam penelitian 
ini peneliti menggunakan prosedur Triangulasi Teknik.

\section{Hasil dan Pembahasan \\ Persepsi Masyarakat dalam Menanggapi Iklan Politik di Televisi}

Berdasarkan hasil temuan dan data yang telah diperoleh, dapat dikatakan bahwa periklanan politik di televisi terbilang bagus dan efektif. Iklan secara umum merupakan sarana bagi upaya menawarkan barang, jasa, tempat usaha, dan ide yang disampaikan melalui media dengan biaya sponsor untuk ditujukan kepada khalayak luas. Periklanan politik dapat diartikan sebagai suatu tahapan dimana untuk membentuk atau membangun posisi-posisi kekuasaan didalam masyarakat yang berguna sebagai pengambilan keputusan-keputusan yang terkait dengan kondisi masyarakat.

Iklan politik juga dikatakan merupakan periklanan citra atau jati diri, daya tarik. Hal ini juga sesuai dengan pendapat Istiqomah (2013) dikatakan bahwasanya media dan kemajuan teknologi juga dimanfaatkan oleh pelaku atau kepentingan politik, khusunya dalam pembentukan pencitraan yang dapat diwujudkan dalam kemasan-kemasan atau rancangan yang telah dibuat sebelumnya guna mendapat perhatian lebih dari masyarakat. Namun, mengenai periklanan politik di televisi juga dikatakan masih rentan akan unsur manipulatif. Pernyataan selanjutnya dikemukakan oleh Retnowati (2013) bahwasanya periklanan politik yang sering muncul di media massa didominasi oleh unsur pembentukan suatu citra oleh para calon peserta, khususnya yang menarik dengan membela kepentingan rakyat. Jadi, semakin banyak pembentukan unsur citra maka akan meningkatkan popularitas disertai peningkatan elektabilitas.

Proses pembentukan suatu citra pada hal ini diarahkan untuk membangun reputasi seseorang pejabat publik mengenai kualifikasi seseorang politisi, latar belakang, pengalamannya, kepribadiannya, sehingga merupakan dorongan bagi prospek pemilihan calon atau kandidat yang bersangkutan dalam proses politik. Hal ini sesuai dengan penelitian yang dilakukan oleh Haryati (2007) mengenai periklanan adalah bagian terpenting dari serangkaian kegiatan untuk mempromosikan produk yang menekankan citra. Dalam penelitian tersebut juga dikatakan bahwasanya kegiatan politik tidak bisa terlepas dari media, dengan menggunakan media massa dapat mendeskripsikan para calon peserta politik meliputi pengenalan tokoh, visi dan misi, karakter, dan progam-progam yang ditawarkan, serta yang paling penting adalah dengan melakukan aktifitas politik melalui media televisi bisa dikatakan akan mampu mencakup khalayak luas. Hal tersebut juga sesuai dengan pernyataan Ariviyanti (2017) bahwasanya sangat penting untuk pembentukan suatu citra di masyarakat guna tersampainya pesan politiknya. Citra diantaranya meliputi persepsi mengenai calon atau kandidat tokoh, banyak membuat progam yang mendukung kepentingan rakyat, penyampaian progam yang ditawarkan, dan peristiwa seperti tindakan nyata yang ditampilkan dalam bentuk visual misalnya. Hal tersebut dirasa akan meningkatkan popularitas dan daya tarik tersendiri di masyarakat.

Kegemaran menonton televisi oleh masyarakat bisa dikatakan mampu mencakup khalayak luas, baik itu anak-anak, remaja, dewasa, dan orang tua. Tayangan iklan politik yang dimunculkan dalam media televisi memunculkan suatu persepsi dari khalayak penonton yang melihatnya. Tayangan yang ditampilkan oleh para calon peserta politik kemudian dilihat oleh masyarakat yang menontonnya akan menimbulkan suatu pemikiran dan tanggapan mengenai hal tersebut, menjadikan masyarakat akan menafsirkan makna maksud isi pesan kemudian disertai dengan respon dan tindak lanjut setelahnya.

Terkait dengan persepsi masyarakat mengenai periklanan politik di televisi dari hasil penelitian yang telah dilakukan adalah bahwasanya sangat efektif. Hal ini sesuai dengan pendapat Alda (2009) bahwasanya informasi atau tayang iklan politik yang 
ditampilkan mudah dan dapat diterima dengan baik, serta dianggap mewakili kenyataan yang mereka ketahui. Iklan politik efektif untuk pembuatan persepsi khususnya citra jati diri, jika dilakukan dengan baik maka akan mampu membuat pola pikir khalayak berkesinambungan dengan apa yang dikirim atau diinginkan oleh komunikator.

Tayangan iklan politik juga efektif dilakukan melalui media televisi, karena salah satu kelebihannya adalah kemudahan dan keterjangkauan bagi khalayak luas. Pada penelitian ini dibuktikan dengan bahwasanya iklan politik di televisi dapat menambah wawasan politik khususnya orang awam, mengetahui para calon peserta, dapat memilah dan memilih peserta yang layak, mengetahui visi dan misi, tokoh yang ditampilkan, dan karena televisi memiliki kelebihan audio dan visualnya sehingga menciptakan daya tarik tersendiri bagi masyarakat yang menontonnya.

Terkait dengan persepsi masyarakat jika dikaitkan dengan pernyataan di atas adalah bahwasanya dalam memberikan tanggapan mereka mengacu pada apa yang dilihat oleh indra mereka. Setiap individu dalam memahami dan menafsirkan apa yang mereka lihat berbeda dengan yang lain, hal ini bisa dikarenakan faktor kepribadian, status, dan lingkungan. Hal tersebut juga sesuai dengan hasil penelitian yang dilakukan oleh Priyanti (2013) bahwasanya ditemukan iklan politik atau kegiatan politik di televisi mampu menciptakan suatu penafsiran oleh masyarakat, dalam hal ini adalah kondisi dan keyakinan serta tayangan yang telah dilihat oleh masyarakat dikatakan bisa mempengaruhi perilaku politik masyarakat.

\section{Dampak Iklan Politik Terhadap Hak Pilih Masyarakat}

Periklanan politik melalui media televisi berdasarkan hasil temuan dan data yang telah diperoleh terbilang bagus dan efektif karena mampu mencakup khalayak luas, hal ini juga sesuai dengan hasil penelitian Haryati (2007) adapun aktifitas atau periklanan politik lewat media massa cetak maupun elektronik dirasa lebih efektif, salah satunya dikarenakan media massa mampu mencapai khalayak luas.

Namun, melalui kegiatan tersebut tentu berdampak bagi masyarakat, misalnya terhadap pilihan mereka. Ada yang memang dari awal telah memiliki pandangan serta ada juga yang sebelumnya belum memiliki pandangan lalu terbawa opini politik yang ditayangkan, begitupun juga yang telah memiliki pandangan karena alasan tertentu berpindah pilihan dengan yang lain.

Pernyataan lain mengenai dampak iklan politik terhadap hak pilih masyarakat juga dikemukaan oleh Arif \& Ama (2015) bahwasanya iklan politik di televisi terdiri dari elemen isi pesan, struktur, format pesan, dan sumber pesan dimana kesemuanya meliputi beberapa hal seperti menarik, edukatif, informatif, penampilan ilustrasi, dan lain sebagainya yang dapat menimbulkan suatu persepsi di masyarakat serta menimbulkan suatu pertimbangan tersendiri atau bahkan dapat mempengaruhi dalam pengambilan keputusan, khususnya bagi pemilih pemula.

Berdasarkan temuan data yang telah diperoleh, periklanan politik di televisi memiliki kelebihan dan kekurangan bagi masyarakat. Kelebihannya diantaranya, iklan politik dapat menambah wawasan politik, bisa mengenal dan mengetahui para calon-calon peserta, mengetahui visi dan misi, meningkatkan partisipasi, serta dikarenakan televisi memiliki kelebihan yaitu audio dan visualnya, sehingga iklan yang ditayangkan tersebut akan memiliki citra daya tarik tersendiri bagi masyarakat yang menontonnya. Hal tersebut juga sesuai dengan pendapat Rubyanti (2009) dikatakan bahwasnya alasan utama masyarakat menaruh perhatian khusus pada kegiatan politik dan keputusan memilih sangat mempertimbangkan isi yang termuat didalamnya, dalam hal ini adalah calon peserta, visi dan misi serta progam-progam yang menarik yang ditawarkan kepada masyarakat. 
Selain memiliki kelebihan, periklanan politik di televisi juga memiliki kekurangan diantaranya, durasi iklan yang terbilang sedikit, beberapa isi dan pesan yang kurang jelas, kendala dalam hal penafsiran maksud iklan tersebut, kebenaran isi yang ditampilkan, serta dapat mempengaruhi khusunya pertimbangan terhadap pilihan mereka. Hal ini juga sesuai dengan pendapat Ismail (2018) bahwasanya dalam penyampaian iklan atau kampanye politik baik lembaga penyiaran, kontestan, memiliki kesamaan dan berkomitmen mematuhi peraturan yang ada. Dalam hal ini meliputi pengenalan, penyampaian isi, visi dan misi serta janji-janji yang ditawarkan harus sesuai, jadwal kapan waktu kampanye berlangsung dan kapan harus selesai. Khususnya dalam hal ini adalah mereka tidak boleh ada keberpihakan dan harus mementingkan kepentingan rakyat.

Terkait dengan hak pilih masyarakat bisa dibilang meningkatkan partisipasi, namun iklan politik juga bisa mempengaruhi kondisi dan keyakinan, penggiringan opini disertai citra menjadi pertimbangan tersendiri bagi masyarakat. Hal ini sesuai dengan penelitian yang telah dilakukan oleh Priyanti (2013) ditemukan bahwa iklan politik atau kegiatan politik di televisi bisa mempengaruhi perilaku politik masyarakat. Semakin tertariknya serta mengikuti aktifitas politik di televisi, masyarakat atau elemen lain bisa terpengaruh dengan apa yang sedang berlangsung. Perilaku politik tersebut meliputi sikap, kondisi, keyakinan dan penentuan kedepan terhadap kegiatan politik.

Terkait dengan periklanan politik di televisi bisa meningkatkan partisipasi masyarakat dan pertimbangan dalam keputusan memilih, hal tersebut sesuai dengan pernyataan Darmawati (2015) dikatakan bahwasanya periklanan politik yang disertai dengan pengenalan tokoh, visi misi, khususnya progam yang ditawarkan dapat meningkatkan partisipasi dan cukup mempengaruhi minat memilih masyarakat dalam suatu pemilihan. Hal ini juga sesuai dengan temuan Suryatna (2011) dikatakan bahwasanya para calon pemilih khussunya pemula banyak menerima terpaan iklan politik melalui media meliputi penyampaian yang jelas seperti pengenalan, visi misi dan progam yang ditawarkan dijadikan pertimbangan tersendiri guna menentukan pilihan.

Pernyataan lain dikemukakan oleh Puspitasari (2014) mengenai keterkaitan iklan politik dengan hak pilih masyarakat pasti ada, namun penentuan keputusannya juga harus mempertimbangkan frekuensi menontonnya. Seberapa sering iklan dilihat atau dibaca begitupun sebaliknya mereka yang hanya sedikit melihatnya dijadikan faktor tersendiri terkait peran iklan politik dalam penentuan pengambilan keputusan di masyarakat.

Namun keterkaitan antara peran iklan politik dalam penentuan pengambilan keputusan tidak sesuai dengan pernyataan Addasuqi (2015) bahwasanya iklan politik tidak bisa menentukan secara keseluruhan khususnya mempengaruhi pengambilan keputusan, melainkan yang menjadikan pertimbangan justru ada pada persepsi atau pemaknaan tafsir dari tiap-tiap individu itu sendiri. Jadi, masyarakat itu sendirilah yang menentukannya.

\section{Kesimpulan}

Persepsi masyarakat dalam menanggapi iklan politik di televisi adalah bahwasanya sangat bagus dan efektif. Seperti melalui media televisi efektif guna penyampaian informasi atau kepentingan politik seperti menambah wawasan politik, promosi, pengenalan tokoh, penyampaian misi dan misi, serta progam-progam yang ditawarkan khususnya pada saat kampanye. Berdasarkan hasil penelitian dikatakan bahwa, iklan politik dapat menambah wawasan politik khususnya orang awam, bisa mengenal dan mengetahui peserta, dapat memilah dan memilih peserta yang layak, mengetahui visi dan misi, serta dikarenakan media televisi memiliki ciri audio dan visualnya, sehingga menjadi daya 
tarik tersendiri bagi masyarakat yang menontonnya.

Dampak iklan politik terhadap hak pilih masyarakat adalah bahwasanya periklanan politik di televisi memiliki kelebihan dan kekurangan tersendiri. Kelebihannya diantaranya, mampu menambah wawasan politik khususnya orang awam, mengenal para peserta, memilah dan memilih peserta yang layak, opini yang dapat meningkatkan partisipasi masyarakat, serta dikarenakan kelebihan televisi memiliki audio visualnya, sehingga memiliki citra daya tarik tersendiri bagi masyarakat. Sedangkan kekurangannya diantaranya, isi dan pesan terkadang kurang jelas, kendala dalam hal penafsiran makna, kebenaran isi yang ditampilkan, serta dapat mempengaruhi khusunya pertimbangan terhadap pilihan mereka.

Terkait dengan hak pilih masyarakat bisa dibilang meningkatkan partisipasi, namun iklan politik juga bisa mempengaruhi kondisi dan keyakinan mereka.

\section{Daftar Pustaka}

Ariviyanti, Betari Chintya dan Syilvie Nurfebiaraning. 2017. Analisis Aktifitas Pembentukan Citra Politik Hary Tanoesoedibjo. Jurnal Ilmu Komunikasi, (Online), 5(01): 48-58, (http://journal.uad.ac.id/index.php /CHANNEL/article/download/635 3/3356) diakses 14 Agustus 2019

Addasuqi Syarief, Achmad. 2015. Pengaruh Iklan Politik Peserta Pemilu dan Persepsi Pemilih Terhadap Pengambilan Keputusan Ditinjau dari Tempat Tinggal dan Jenis Kelamin pada Pemilu Legislatif 2014 di Desa Tapis Kecamatan Tana Paser. Jurnal Psikologi, (Online), 4(01): 65-78, (http://ejournal.psikologi.fisipunmul.ac.id/site/wp-
content/uploads/2015/11/JURNA

L\%20fix\%20(11-13-15-01-59-53)

diakses 14 Agustus 2019

Alda, Isnina. 2009. Persepsi Khalayak Terhadap Iklan Politik (Studi Deskriptif Kuantitatif Mengenai Persepsi Siswa SMA Negeri 2 Solo Terhadap Iklan Politik Soetrisno Bachir pada Televisi. Jurnal Ilmu Sosial (Online), 2(02) : 46-75 https://digilib.uns.ac.id/dokumen/ download/14811/Mjk2ODA=/Per sepsi-khalayak-terhadap-iklanpolitik-studi-deskriptif-kuantitatifmengenai-persepsi-siswa-SMANegeri-2-Solo-terhadap-iklanpolitik-Soetrisno-Bachir-padatelevisi-abstrak.pdf diakses 10 Desember 2018

Arif .R., S.Ama. 2015. Pengaruh Iklan Politik Televisi Terhadap Pilihan Politik Calon Pemilih Pemula di Indonesia. Jurnal Manajemen Bisnis Telekomunikasi dan Informatika (Online), 2(02) : 2355-9357,

https://openlibrary.telkomuniversi ty.ac.id/pustaka/files/102073/jurn al_eproc/pengaruh-iklan-politiktelevisi-terhadap-pilihan-politikcalon-pemilih-pemula.pdf diakses 10 April 2019

Cangara, Hafied. 2003. Pengantar Ilmu Komunikasi. Jakarta: PT. Rajagrafindo Persada

Darmawati. 2015. Hubungan Iklan Politik di Televisi Terhadap Minat Memilih Masyarakat dalam Pemilihan Umum Presiden 2014 di Desa Simalinyang RT 30 RW 12 Kabupaten Kampar. Jurnal 
Risalah (Online), 26(03): 109-116, https://media.neliti.com/media/pu blications/127909-ID-hubunganiklan-politik-di-televisi-terha.pdf diakses 10 April 2019

Haryati. 2007. Ketika Parpol Mengiklankan Kandidatnya di Televisi. Jurnal Mediator, (Online), 8(02): 67-89, https://ejournal.unisba.ac.id/index. $\mathrm{php} / \mathrm{mediator} /$ article/view/1251/8 08 diakses 10 Desember 2018

Ikhna Priyanti, Maezi. 2013. Peranan Media Televisi Dalam Pembentukan Perilaku Politik Berkenaan dengan Pilkada Jawa Tengah. Jurnal Ilmu Sosial (Online), 2(02): 65-87 (http://lib.unnes.ac.id/19982/1/330 1409076.pdf) diakses 10 Desember 2018

Ismail, Ervan. 2018. Kontrovesi Iklan Politik dalam Pilkada DKI Jakarta 2017. Jurnal Prespektif Komunikasi (Online), 1(03): 81112 ,

(http://jurnal.umj.ac.id/index.php/ perspektif/article/download/3890/ 2887) diakses 14 Agustus 2019

Istiqomah Rahmatul, Ria. 2013. Kampanye Politik di Televisi sebagai Budaya Populer. Jurnal Interaksi (Online), 2(02): 90-97, https://ejournal.undip.ac.id/index. php/interaksi/article/viewFile/659 2/5425 diakses 10 April 2019

Kuswandi, Wawan. 2008. Komunikasi Massa Analisis Sebuah Analisis Media Televisi. Jakarta: Rineka Cipta
Boer, Kheyene Molekandella. 2014. Iklan Partai Politik dan Politik Media. Jurnal Visi Komunikasi (Online), 13(02): 296-310, http://publikasi.mercubuana.ac.id/ index.php/viskom/article/downloa d/1660/1268 diakses 13 Agustus $\underline{2019}$

Mustofa, Ali. 2013. Peran Media Massa sebagai Saran Iklan Politik Parpol. Jurnal Interaksi (Online), 2(01): 62-69, https://ejournal.undip.ac.id/index. php/interaksi/article/download/54 $\underline{09 / 4845 \text { diakses } 13 \text { Agustus } 2019}$

PKPU (Peraturan Komisi Pemilihan Umum) Republik Indonesia Nomor. 33 Tahun 2018 Pasal 37

Puspitasari Dwi, Rizky. 2014. Opini Mahasiswa Surabaya Terhadap Iklan Politik Partai Nasdem Melalui Media Televisi. Jurnal Commonline Departmen Komunikasi, (Online), 3(02): 7894,

(http://journal.unair.ac.id/COMN @ opini-mahasiswa-surabayaterhadap-iklan-politik-partainasdem-melalui-media-televisiarticle-7364-media-137-category8.html) diakses 14 Agustus 2019

Retnowati, Yuni. 2013. Efektifitas Iklan dalam Meraih Partisipasi Politik. Jurnal Wacana, (Online), 12(03) : 78-89,

(http://journal.moestopo.ac.id/inde x.php/wacana/article/view/123/68 $\lcm{\text { diakses } 14 \text { Agustus } 2019}$

Rubyanti, Rika. 2009. Pengaruh Popularitas Terhadap Pilihan Pemilih Pemula. Skripsi pada 
Universitas Sumatera Utara: Tidak Diterbitkan

Shauma, Anisatus dan Zainal Abidin A. 2015. Efektifitas Iklan Politik di Televisi. Jurnal Ilmu Komunikasi (Online), 7(02): 102-128

Setiadi M, dan Kolip Usman. 2013. , http://eprints.upnjatim.ac.id/7017/ 1/1.JURNAL_Zainal_2.pdf diakses $13 \quad$ Agustus 2019Pengantar Sosiologi Politik. Jakarta: Kencana Prenadamedia Group

Slameto. 2010. Belajar dan FaktorFaktor yang Mempengaruhinya. Jakarta: Rineka Cipta

Suryatna, U. 2011. Pengaruh Terpaan Media Iklan Politik Terhadap Perilaku Pemilih Pemula. Jurnal Sosial Humaniora (Online), 2(02): 2087-4928, (https:// ojs.unida.ac.id/JSH/article/downlo ad/95/102) diakses 14 Agustus 2019

Tamburaka, Apriadi. 2012. Agenda Setting Media Massa. Jakarta: PT Raja Grafindo Persada

W. Magdalena, Maria. 2010. Tanggapan Masyarakat Terhadap Iklan Politik di Televisi. Jurnal Sosial, (Online), 11(02): 56-87, (http://unmermadiun.ac.id/reposit ory_jurnal_penelitian/Jurnal\%20S osial/Jurnal\%20Sosial\%202010/S eptember/4_\%20Maria\%20M.pd f) diakses 14 Agustus 2019

Yunus, Ulani. 2014. Konstruksi Pesan Politik di Televisi Komersial Menjelang Pemilihan Umum 2014. Jurnal Humaniora (Online), 5(02): 1213-1221, (https://journal.binus.ac.id/index.p hp/Humaniora/article/view/3264/2 648) diakses 14 Agustus 2019 